\title{
THE WAYS IN WHICH BLIND MOTHERS COPE WITH TAKING CARE OF THEIR CHILDREN UNDER 12 YEARS OLD
}

\author{
Herla Maria Furtado Jorge ${ }^{1}$, Juliana da Fonseca Bezerra², Mônica Oliveira Batista Oriá3 , Christina Cesar \\ Praça Brasil ${ }^{4}$, Maria Alix Leite de Araujo ${ }^{5}$, Raimunda Magalhães da Silva ${ }^{6}$
}

\footnotetext{
${ }^{1}$ Ph.D. student in Obstetrics and Gynecology at Universidade Estadual de Campinas. Sao Paulo, Brazil. Email:herla@fcm.unicamp.br

${ }^{2}$ M.Sc. student in the Graduate Program in Public Health at Universidade de Fortaleza (UNIFOR). Ceará, Brazil. Email: ju25fb@ hotmail.com

${ }^{3}$ Ph.D. in Nursing. Assistant Professor at the Nursing Department of Universidade Federal do Ceará (UFC). Ceará, Brazil. Email: monica.oria@ufc.br

${ }^{4}$ Ph.D. student in the Graduate Program in Public Health at UNIFOR. Professor at the UNIFOR. Ceará, Brazil. Email: cpraca@ unifor.br

${ }^{5}$ Ph.D. in Nursing. Assistant Professor at UNIFOR. Ceará, Brazil. Email: mleite@unifor.br

${ }^{6}$ Ph.D. in Nursing. Assistant Professor at UNIFOR. Ceará, Brazil. Email: rmsilva@unifor.br
}

\begin{abstract}
This study was aimed at analyzing the ways in which blind mothers cope with taking care of their children under 12 years old and is focused on health promotion, risk prevention and education. This is a qualitative study held in Fortaleza, in the state of Ceará, at the homes of nine blind mothers. A semi-structured interview was performed, from which the core meanings emerged: suitability of the home environment in order to prevent domestic accidents; prevention and treatment of diseases and monitoring of education. Data analysis was based on the concepts of coping and symbolic interactionism. The fact that the mothers are aware of the suitability of the home environment was evident. The pursuit for health promotion was done through the demand for healthcare system. Concerning education, the mothers are aware of the importance of the study and of monitoring its development. Despite the limitations and difficulties, it was observed that they care for and educate their children with the intention of raising good natured and responsible people for the society.
\end{abstract}

DESCRIPTORS: Education of visually disabled; Child care; Mother-child relations.

\section{ENFRENTAMENTO DE MÃES CEGAS NO ACOMPANHAMENTO DOS FILHOS MENORES DE 12 ANOS}

RESUMO: Objetivou-se analisar o enfrentamento de mães cegas no cuidado dos filhos menores de 12 anos, com ênfase na promoção da saúde, prevenção de riscos e educação. Trata-se de um estudo qualitativo desenvolvido em Fortaleza-CE, no domicílio de nove mães cegas. Aplicou-se uma entrevista semiestruturada, em que emergiram os núcleos de sentido: adequação do ambiente domiciliar para a prevenção de acidentes domésticos; e prevenção e tratamento de doenças e acompanhamento da vida escolar. A análise dos dados fundamentou-se nos conceitos de enfrentamento e interacionismo simbólico. Evidenciou o fato de que as mães têm consciência da adequação do ambiente domiciliar. A busca da promoção da saúde deu-se pela procura do sistema de saúde. Quanto à educação, as mães compreendem a importância do estudo e de acompanhar o seu desenvolvimento. Apesar das limitações e dificuldades, observou-se que elas cuidam e educam seus filhos com a intenção de formar pessoas de boa índole, responsáveis, para a sociedade.

DESCRITORES: Educação de pessoas com deficiência visual. Cuidado da criança. Relações mãe-filho.

\section{AFRONTAMIENTO DE MADRES NO VIDENTES QUE ACOMPAÑAN A SUS NIÑOS MENORES DE 12 AÑOS}

RESUMEN: Se objetivó analizar el enfrentamiento de las madres no videntes en el cuidado de los hijos menores de 12 años enfatizando en la promoción de la salud, prevención de riesgos y la educación. Estudio cualitativo desarrollado en la ciudad de Fortaleza-CE, en la casa de nueve madres no videntes. Se aplicó una entrevista semi-estructurada de la cual surgieron los núcleos de sentido: adecuación del ambiente del hogar para la prevención de accidentes; prevención y tratamiento de las enfermedades y seguimiento de la vida escolar. El análisis de datos se basó en los conceptos de enfrentamiento y en el interaccionismo simbólico. Se evidenció que las madres son conscientes de la adecuación del ambiente en el hogar. Con relación a la educación, las madres comprenden la importancia del estudio y de acompañar el desarrollo escolar. A pesar de las limitaciones y dificultades, se observó que ellas cuidan y educan sus hijos basados en buenos principios sociales.

DESCRIPTORES: Educación para discapacidad visual. Cuidado del niño. Relaciones madre-hijo. 


\section{INTRODUCTION}

According to the National Health Policy for People with Disabilities, the term disability is related to every loss or abnormality of a psychological, physiological or anatomic structure or function, which causes incapacity to perform activities, within the standards considered normal for human beings. ${ }^{1}$ In Brazil, according to the last demographic census, there are about 45 million people with disabilities and, from these, 35,791,488 are visually disabled. ${ }^{2}$

Visually disabled mothers take care of their children with the aid of other senses, especially touch, hearing and smell. These mothers are guided by healthcare professionals who use alternative ways, such as the hands, to help learning information. Cordel literature can also be mentioned as an example, since it helps to explain topics such as: techniques concerning child care, the correct ways of preventing sexually transmitted diseases (STDs), breast self-examination, among others. ${ }^{3}$

Children's growth is related to genetic factors and to the environment where they live. The growth varies according to their nutrition, practice of sports and exposure to infectious diseases. ${ }^{4}$ Therefore, monitoring their development and directing their family members and caregivers strengthen the bond between families and healthcare services, focusing on health promotion through actions, such as the guidance about healthy life habits, vaccination, prevention of problems and diseases and provision of care in a timely manner.

In order to provide this care to their children, the mothers need to change life habits. According to a study involving women who take care of disabled children, they experience a situation of pain and stress which affects their own well being, because a good mother, regardless of being or not disabled, needs to follow a standard: to be dedicated, careful and selfless. Thus, they isolate themselves and this attitude sometimes causes marital and social break-ups, which requires the reorganization of the family dynamics. ${ }^{5}$

The family-centered care is aimed at health promotion and well being of all its members, restoring their control and dignity. The definition of family is given by the members themselves and the actions are not limited to the biological body, while the emotional, social and developmental supports are considered components of healthcare. Despite being centered on the family, the care does not eliminate each member's ability to make decisions about their health and the priorities in their lives, which leads mothers to change their behavior towards society. ${ }^{6}$

A search was performed on the online databases Pubmed, Scielo and Medline, in 12 June 2012, using the following descriptors: education of visually disabled people, care, mothers and children. Two hundred and forty seven articles (247) were found. However, after analyzing the summaries, only 20 were found to be relevant to the topic and were published between 2008 and 2012. It must be highlighted that none of these articles was focused on the specific topic about blind mothers taking care of their children. The lack of publications about this subject encouraged the authors to develop a research with this vulnerable population, often unknown to society.

Based on the recommendations of Brazil's Ministry of Health, as a guide for child care promotion, and due to the difficulties faced by mothers who are fully or partially visually disabled, it is asked: how do blind mothers cope with taking care of their children aged under twelve, considering their ways of caring and educating?

The aim of this study was answering this question, and this was performed by the analysis of the ways that blind mothers do so focusing on health promotion, risk prevention and education.

The understanding about the way mothers cope with this situation was sought ${ }^{7}$ and this was associated with the concepts of interaction and interpretation of meanings revealed in the symbolic interactionism scope. ${ }^{8-9}$ This study was justified by the need to expand scientific literature in order to support the healthcare professionals in charge of meeting this demand, besides offering a contribution to formalize strategies and reflections aimed at providing mothers with tools to promote a safer care for their children.

\section{THEORETICAL FRAMEWORK}

To further analyze the object of this research, the theoretical coping approach was used, showing that human beings are conscious agents who provide meaning to situations and seek to act in a self-directed and motivated way. From this perspective, coping is defined in the following aspects: (a) coping is a process or interaction between a person and the environment; (b) its role is to administer the stressful situation, rather than controlling or dominating it; (c) coping assumes 
the idea of evaluation, that is, the way in which the event is viewed, interpreted and cognitively represented in the person's minds; and (d) coping is a mobilization of strategies, in which people make cognitive and behavioral efforts to administer the internal or external demands that result from their interaction with the environment. ${ }^{7}$ Besides, interactive concepts that emphasize the importance of the meaning and the idea that this has a central role in the social process were shown. ${ }^{8}$

Coping basically deals with two concepts: ${ }^{7}$ the first is the threat, which primarily results from a stressful event that is faced by the mothers, and that is shown to people as a threat to be faced; the second is the concept of control. Due to the threat posed by the stressful event, people search for coping mechanisms to have control of the situation, of themselves and their feelings. ${ }^{8}$

Coping mechanisms are attempts to avoid and resist the disruptive and stress causing events. Researches ${ }^{5,7}$ indicate that people can express forms of reaction more or less effective and may be influenced by several factors, such as: home and social environments, life history and personal features. ${ }^{7}$ In the 1940s, coping was defined, according to the theory describing it, as defense or self-defense mechanisms that are associated with the ego's functioning and psychology. Thus, the coping model arises as personality traits and styles, in which this attitude is addressed as a stable predisposition that allows people to react to stressful events, facing them or adjusting before them, with a view of structuring or restructuring. ${ }^{\text {? }}$

As an effect, coping is defined as a set of cognitive or behavioral efforts, used by people with the purpose of dealing with specific internal or external demands arising from stressful situations that either overload or exceed personal resources.? This definition understands that coping strategies are deliberate, can be learned, used or discarded. Therefore, unconscious and unintentional defense mechanisms, such as denial, displacement and regression cannot be considered as coping strategies.

Coping has two important roles: to regulate the emotional response to stressful events, that is the coping focused on the emotion; and to control or change the problem that caused the negative stress, that is to leave the coping focused on the problem. ${ }^{6}$ This model is based on a cognitive perspective, which is defined as a psychological perspective while it suggests that the study about the manner in which people think will lead to a broad insight concerning human behavior.
The symbolic interactionism involves three assumptions, according to which human beings act in relation to the meanings that things have for them. These meanings are a result of a social interaction and are manipulated and modified according to an interpretative process of people with the familiarity of the events. ${ }^{8}$

In this study, these assumptions were sought after, in order to find out the intrinsic meaning of the care provided by blind mothers to children under 12 years old, giving rise to internal perceptions and conscious interpretations about the health and education of their children.

These aspects will have meaning to people when they consciously consider them, reflect and think about or interpret the object. This is processed through an internal conversation in which the person selects, checks, suspends, regroups and changes the meanings according to the situation they are in and the direction they gave to their action. ${ }^{9}$

Human being should be seen as creative, innovative and free to realize the essence of the relationship between mankind and society. From this perspective, the interactive theory defends the argument that the actions should be combined with the experiences manipulated by people, which involves coping with a series of situations in which they must act and the way they evaluate and interpret them. ${ }^{8}$

\section{METHODOLOGIC DESIGN}

This is a descriptive study with qualitative approach, undertaken in Fortaleza-CE, in blind women's homes. It was sought to view the mothers in the reality of their social context and taking subjectivity into account, which allowed the understanding of changes in the social relationships.

The participants of the study were blind mothers, without age restriction, who were in physical and emotional conditions of taking care of their children aged under 12 years old, whose age refers to the dependency stage of people in relation to their parents or caregivers; whether or not these children had any kind of disability.

The access to the subjects of the study occurred by searching at blind people's associations, in the capital of Ceará, which have the registration of most visually disabled people, based on an indication of a researcher who conducts studies involving blind women and on information provided by the mothers participating in the study. Also, the snow ball scheme was used, which is 
based on the request to the initial members to indicate other people with compatible profile in relation to the study's selection criteria. ${ }^{10}$ Based on these, nine mothers were identified and contacted by phone to get information about the objectives of the study and the schedule home visits. There was no refusal by any of the people identified to participate in the study.

For data collection, a semi-structured interview was performed, involving personal and socio-demographic details, as well as the guiding questions: what are the preventive measures you take in the care for your children against domestic accidents? How do you promote health and offer food to your children? What are the educational practices developed with the children?

During the interview, the home environment was directly observed to assess the suitability and structure of the houses, as well as their socioeconomic and educational condition, in order to complement and further analyze the data. The completion of the interviews occurred when repetitions of meaning were verified in the statements and due to not having indication of other blind mothers to join in the study.

The data collected were used to perform the content analysis, ${ }^{11-12}$ in the thematic model. For the identification of the themes, three guiding questions were gathered in a spreadsheet, correlating the answers of each participant concerning the care for their children. Then, a new reading was performed, which resulted in the identification of seven core meanings, ${ }^{13}$ and the result was summarized in three topics: suitability of the home environment for prevention of domestic accidents; health promotion strategy and care for the children and monitoring of the educational life. In order to maintain people's anonymity, the letter " $\mathrm{M}$ " was used, followed by the numbers 1 to 9 , to identify the statements of the participants.

This research was approved by the Ethics Committee Research of the de Fortaleza University, under registration number 067/2011, complying with the legal and ethical aspects according to the applicable law at the time Resolution number 196 of 10/10/1996, which regulates researches involving human beings. ${ }^{14}$

\section{RESULTS AND DISCUSSION}

The nine participants were in the age group between 20 and 55 years old and their children were not visually disabled. Some had other children who were above 12. Concerning the educational level, most mothers had completed high school and one was graduated and undertaking a postgraduate course, which probably makes possible to have the knowledge, the values and the attitudes for both health promotion and the children education. The mothers who were married lived with their husbands and children, and the single ones lived only with their children; within some families, there was another person to help with the housework. All of them stated to be religious; five of them were catholic, three evangelic and one spiritualist.

It was verified that, even with low socioeconomic status, the participants' homes were comfortable for the children, with an exclusive room for them, healthy and appropriate food, clean clothes, toys and organized school material. In all of the nine families, the school-aged children had access to school. The physical structure of the houses was of good quality, with lined ceilings and appropriate ceramic floorings, clean bathrooms and organized rooms. The electrical appliances were new in six of the visited houses. There were entertainment goods, such as TV and DVD, in all households. Computers were used in two homes. In three homes, there were well looked after pets which the children played with.

It was observed that the mothers were sensible, determined and had coherent answers to the experienced situation, making use of personal resources to cope with taking care of their children.

\section{Suitability of the home environment for the prevention of domestic accidents}

Concerning the set of analyzed statements, there was recurrence of the suitability of the home environment with emphasis on the removal of sharp objects, cleaning products at children's reach and the modification of the physical structure for accident prevention.

The mothers were aware of the preventive measures of domestic accidents and most of them adapted the environment to the needs established according to ages of the children. For illustrative purpose, they highlighted the following: I have always been careful and kept the knives at a high place and asked the secretary to be alert (M7); everything can cause children's accidents and there are electrical outlets, sharp objects, cleaning products and fire (M9); there are windows, which I will put bars on (M3); I put my daughter on the hammock and on the bed with protection on both sides, so that she does not roll over and fall (M6). 
It is noteworthy the fact that one of the mechanisms used as the mothers' perception to prevent domestic accidents is the use of the language: $I$ say, look, if you go, you are going to get burnt, it will hurt and get sick (M1). What is expressed shows a relationship between the mothers' perceptions regarding prevention of domestic accidents with the knowledge acquired within society to develop strategies and perform the adjustment of the home environment according to their disability.

Due to the concern of these mothers to adapt the domestic environment, some reported limitations and difficulties facing this harmonization. Three of them reported not to pay attention to the suitability of the environment, because they have had the assistance of other people since the birth of the children: my mother helps, but when I am alone with my daughter, I always worry about closing the windows (M3). Even with this concern, accidents have happened, like falls from hammocks, walkers, beds and walls, electrical shocks and various cuts.

The findings showed the knowledge and efforts made by these mothers to adapt the home environment as strategy to prevent domestic accidents, and this reinforces the coping as interaction between the people and the environment. ${ }^{7}$ The used tactics are part of a conscious way of care that is limited in relation to the development and interpretations of actions by the mothers.

Based on the statements, and observing the characteristics of the home environment, it was observed that the family life is a process of formation, support and transformation of objects, in so far as their senses are modified. Human beings are capable of pointing out things to themselves and this means that, when facing the universe of objects around them, they should interpret them in order to act and establish an action route based on this interpretation. ${ }^{8}$

Family support for blind women is also highly relevant to them, and is one of the factors that encourage them to face the difficult situations in life. A mother of three children stated: when I decided to have children, my mother thought it was awful and, to me, this is my greatest difficulty, because my mother does not support me (M9).

This autonomy that the mothers are able to achieve, even without the support of family members, is increased according to the relationship of the human being with the environment and it happens regardless of the context in which one is. ${ }^{9}$

A previous study ${ }^{3}$ indicates the prevention of domestic accidents, such as: to store cleaning products or toxic and caustic ones in an appropriate place, and getting children away from the stove, windows and stairs. Accident prevention is part of the ability of blind people to perform daily tasks, and first aids may be taught with adequate educational technology. ${ }^{3}$ Another study showed that mothers have difficulties during bath time, like being insecure about the temperature of the water, the occurrence of accidents and on products to be used to wash the children. The alternative for mothers to overcome this hurdle is using the senses of touch and smell, besides organizing the utensils in order and applying security measures which give mothers self-confidence and preserve the children's wellbeing. Thus, the strategy of adapting the environment is an alternative for coping with the situation according to their disabilities. $^{7}$

The study addresses the children of blind mothers, who may be more vulnerable to accidents, even though there is not a comparative study that highlights accidents with children of blind mothers, it is known that accidents and violence are significantly important within children and adolescents' population, and are classified into the group of external causes. In these groups, deaths from these causes accounted for an average of $15 \%$ of the annual deaths in 2008 due to external causes in Fortaleza-CE, and these are the first causes of death in children over five years old. ${ }^{15}$

\section{Strategies for promotion of health and children's care}

Concerning this subject, it was observed that all participants sought health promotion by seeking the healthcare system for vaccination, pediatric appointments and medical assistance to their children. The participants reported identifying health problems using their senses of touch, hearing and smell. For the pediatric appointments, the mothers sought the healthcare units monthly until the children completed one yearand, after that, this was done every six months or when they needed to see a doctor. Five of them made use of private healthcare, and the others, primary healthcare service, even feeling discriminated and poorly served: I take my son to the doctor, if there is no unpredictable event, at least every six months (M3); I go to the healthcare unit, but we are very poorly served, they get surprised because I am blind, it even seems unbelievable a blind person to be a mother. I do not like to go there very much (M8). 
The mothers detected the changes in their children's health through their touch and hearing, and with the help of the children themselves. In order to identify the changes, such as sore throat and fever, the mothers revealed: there is a change of appetite, they become a little nauseated and they are already able to tell us (M1). They knew it was colic when: he squeezes himself and bends his legs (M4); he stretched all his body and we start having that mother's insight (M1). When the pain became more intense, they recognized it through the signs: he/she stopped breathing when he/she was in pain, there were some moments without breathing (M8); I realized when she had a headache because her body went all soft (M2); she cries and doesn't stand still, and I try everything and she does not stop crying. Then, I know she is in pain (M2); sometimes she kept touching her ears and we can see that it is a different cry when she wants attention and when she is really in pain (M9).

The reports showed that five children from the studied group are more sensitive and restless when they are sick, and four of them showed a change in their behavior.

The interest in seeking the help of healthcare professionals shows the interpretation of the educational process and its use by the mothers, enabling them to develop their own coping strategies, according to the social and cultural context. In this case, the Family Health Strategy (ESF) should act as a providing agent, so that the mothers can be benefited in relation to the prevention of risks, promotion of health and recovery of damages.

It is believed that caring for children necessarily involves characteristics related to their development which, if not addressed, will affect their adult life's health and performance and, consequently, the society they live in. ${ }^{16}$ It is necessary to address issues that are poorly explored within the healthcare services, as opportunities for learning, monitoring behavioral changes, prevention of accidents, identification of family violence and domestic abuse; all considered essential for health promotion and important for the adult that this child will grow up to be.

It was also observed that the interpretation of blind mothers concerning their children's health issues was done through language and is related to the interactive perception of the language, characterized by the primary symbolic system and is the most important mechanism in the development of the mind and the self. ${ }^{8}$

The reports showed that seven participants found it hard to administer medication to their children: the most difficult is to pour the drops of the medication. I have to put my finger to know how many are dripping not to give too much (M6); I put him to sleep with me (M1), besides having to use an adapted device as thermometer to read the temperature out loud: I used the adapted thermometer (M1). Only two of the mothers did not mention to have had difficulties: to give medication in drops, I used to put it into those plastic cups to hear the drops falling in (M6).

Due to this fact, a reference is made to the publication of the decree number 5,296 of 2 December 2004, which covers the identification of medication in Braille, which has not yet been fully implemented. ${ }^{17}$ The medical prescriptions transcribed into Braille are also an entitlement of visually disabled people. The results of a study ${ }^{18}$ indicated that the professionals in general, such as the healthcare ones, have not worked on their abilities to assist this type of patient and reported not knowing how to communicate with blind and deaf people.

Concerning human beings, however, the regularity may also result in coping, especially cognitive coping. The persistence of the chronic stressful situation can provide the person with the opportunity to learn and to deal with their demands, by avoiding it or distancing themselves from it. ${ }^{7}$

In the health care of the children, there are various ways for mothers to feed them, with the correct handling and hygienic procedures. There is an approach about the way the children adjust to the manner in which their mothers feed them, because some of them ate the food provided, while others needed more incentive on the part of the mothers. Thus, it is believed that people express more or less effective ways of reacting to various situations, and may be influenced by ecological and social environments, life history and personal features. ${ }^{7}$ In this case, the atypical situation involves the fact that the mothers are blind and have to adjust themselves in order to ensure, in their context, a good nutrition and care of their children. For these mothers, the result of their coping is positive, since all of them reported that, in relation to growth and development, their children are progressing within the desired standards concerning weight and height.

Five mothers liked cooking new dishes to their children: [...] I always make it, I love cooking, I used to do everything, soup, mashed food and I even invented something different sometimes (M1). One 
mother mentioned that she made all the food using a blender, and another mother asks other people's help to prepare her daughter's meals: I do not make her food. Who makes it is my mother, I do not make it because my mother is always with me (M3); and two mothers reported to have only prepared formula to their children.

As for the cleaning of the utensils, all participants washed and boiled the objects used. Only one was more cautious in relation to the cleaning of fruits and vegetables: [...] I always scald or use that hypochlorite or some drops of bleach to soak and then wash after under running water. Ah, I am very cautious about it (M1); I always put my finger in. Of course, I cannot go all the way, but I always use the little brush (M4).

Blind mothers develop strategies to create a balance between their disabilities and the environment, allowing the repetition of the stressful event to be interpreted in a softer way until it stops being stressful.

Due to this fact, it is argued that personal factors give meaning to an event or a situation in which the human being is inserted; for this, it is necessary to develop factors that have the potential to pose a threat. ${ }^{7}$ These variable situations may be important in establishing wellbeing.

\section{Monitoring of educational life}

In relation to education, the mothers understood the importance of their children's studies, showing they are women that are up to date with the social reality in Brazil. The mothers tried hard to educate their children by encouraging them to perform extracurricular activities, promoting reading, monitoring them at home and giving good examples of life and citizenship.

The family and the school have a continuous relationship concerning the education of the children, and the parents need to work together with the school in order to teach them values and limits, since, in the last decades, there have been many changes in the way childhood is viewed, as well as in the roles to be performed by adults in relation to children and young adults. This is justified by the fact that the family, as an institution, is the agent that takes responsibility for the children's education since they are babies and for a longer period; and the schools, nowadays, have increased roles and also act since the first years of childhood. ${ }^{19}$

Based on this reality, blind mothers have shown to have this knowledge and used strategies for monitoring school life, by going to the school, or even signing the diary, encouraging the studies by helping with the homework. To educate their children, all the mothers had direct help from other people, who were their husbands, mothers, siblings or friends.

As for the monitoring of school life, it was observed that two mothers directly monitored the studies of their children: [...] I monitor, although this is more difficult in the homework, I always ask someone to read the diary. I sign the diary every day (M1); I stay with them while they do homework and play afterwards (M9). All of the mothers encouraged their children to study and state: I tell him to read, I always ask him to tell me to see if he understood, I put him to watch the news and I try to read to be up to date (M1).

The guidance concerning sex and drugs are exposed according to the age of each child; even those who have small children intend to talk to them and some reported that they already think about these issues in order to be better prepared for when they talk to their children. The mothers stated: I already talk to my son about everything because, in his classroom, there has been a boy that got involved with drugs, so I need to openly talk to him (M8); now I already talk to my older son, I slowly explain to him. I am open for them to talk to me when they have a question, so they do not go looking for a friend, who teaches them the wrong thing (M1); I intend to provide guidance, because this was the education I have had from my mother, so I want to explain everything to my daughter (M7).

The mothers are able to cope, because they seek strategies to overcome these limitations caused by the disability. They ask their children to read their homework, sign the diary, seek the teachers' guidance to educate their children, understand how they behave at school and analyze the stressful situations that arise.

The education and guidance provided by blind mothers to their children express conflicts, due to the fact that they require the help of other people to educate or impose limits. From this perspective, it is believed that the school, besides being an institution responsible for the development of formal knowledge, also has an important role in establishing limits to the children in conjunction with the parents. ${ }^{20}$

\section{FINAL CONSIDERATIONS}

The study involves a group of blind mothers and it enables an analysis of these women's reality while taking care of their children aged under 12 years old. 
Within the scope of the research, coping strategies of the studied group were identified by the knowledge that these mothers have in relation to domestic hazards and by the ways in which they structure the home environment against accidents. Concerning the suitability of the houses, it was observed that they have adequate structure and good organization, thus providing a proper place for the healthy growth of children without any hazards.

The observations made refer to the idea that the mothers who take care of their children by themselves are able to feed them and properly promote the cleanliness and preparation of the food, since they are more independent to provide care.

Another skill shown by the mothers involved in the research is the use of strategies to identify and resolve the factors that affect their children's health, continuously seeking health promotion. Thus, the ability to detect that the children are sick or hurt is expressed through agitation and the desire to solve the problem, showing good skills to resolve it.

The mothers can adapt to stressful events when taking care of their children, some with the help of other people, and others with determination and creativity, as they think, redesign ideas, recreate strategies and methods to adequately implement all the care.

The feeding and food preparation are always sensitive issues when it involves children; however all of them find a way to properly make food and feed their children, encouraging them through playing or offering a variety of dishes during the meals.

The interviewees understand the importance of monitoring the studies and of giving a good education to their children, because they showed to have a broad view of the society. The women reported a desire to excel in society and family when they decided to have children, and the purpose was achieved because, even having limitations, they can take care and educate these children, raising people with good attitude for a society that deserves to be free of discrimination.

\section{ACKNOWLEDGEMENTS}

Our thanks to FUNCAP and to UNIFOR, for the support given for the research and to the $\mathrm{CNPq}$, for the encouragement in the research productivity scholarship and scientific initiation.

\section{REFERENCES}

1. Ministério da Saúde (BR). Política Nacional de Saúde da Pessoa Portadora de Deficiência. Brasília (DF): MS; 2008.

2. Instituto Brasileiro de Geografia e Estatística (BR) [página na internet]. Censo Demográfico do ano 2010 [acesso 2011 Jul 12]. Disponível em: http:// www.ibge.gov.br/home/estatistica/populacao/ censo2010/caracteristicas_religiao_deficiencia/ default_caracteristicas_religiao_deficiencia.shtm

3. Pagliuca LMF, Uchoa RS, Machado MMT. Blind parents: their experience in care for their children. Rev Latino-Am Enferm. 2009 Mar-Abr; 17(2):271-4.

4. Ministério da Saúde (BR). Saúde da criança: acompanhamento do crescimento e desenvolvimento infantil. Brasília (DF): Secretaria de Políticas de Saúde; 2002.

5. Neves ET, Cabral IE. Empoderamento da mulher cuidadora de crianças com necessidades especiais de saúde. Texto Contexto Enferm. 2008 Set;17(3):552-60.

6. Pinto JP, Ribeiro CA, Pettengil MM, Balieiro MMFG. Cuidado centrado na família e sua aplicação na enfermagem pediátrica. Rev Bras Enferm. 2010 JanFev; 63(1):132-5.

7. Larazus RS, Folkman S. Stress, appraiasal and coping. New York (US): Springer; 1984.

8. Blumer H. Symbolic interactionism perspective and method. Califórnia (US): Prentice-Hall; 1969.

9. Haguette TMF. Metodologias qualitativas na sociologia. $1^{\mathrm{a}}$ ed. Petrópolis (RJ): Vozes; 2007.

10. Albuquerque EM. Avaliação da técnica de amostragem "respondent-driven sampling" na estimação de prevalências de doenças transmissíveis em populações organizadas em redes complexas [Dissertação]. Rio de Janeiro(RJ). Escola Nacional de Saúde Pública Sérgio Arouca - ENSP; 2009.

11. Bardin L. Análise de conteúdo. Lisboa (PF): Edições 70; 2008.

12. Minayo MCS. O desafio do conhecimento: pesquisa qualitativa em saúde. $10^{a}$ ed. São Paulo (SP): Hucitec; 2010.

13. Gomes R. Análise e interpretação dos dados de pesquisa qualitativa. In: Minayo MCS, Deslandes SF, Gomes R. Pesquisa social: teoria, método e criatividade. 28 ed. Petrópolis (RJ): Vozes; 2009. p. 79-108.

14. Brasil. Conselho Nacional de Saúde. Resolução n. 196/96. Estabelece critério sobre pesquisas envolvendo seres humanos. Brasília (BR): Bioética; 1996.

15. Secretaria da Saúde do Estado do Ceará. Situação de Saúde Ceará 2008 [acesso em 2013 abril 12]. Disponível em: http://www.saude.ce.gov.br/ index.php/component/content/article/44764situacao-de-saude-ceara 
16. Moreira MEL, Goldani MZ. A criança é o pai do homem: novos desafios para a área de saúde da criança. Ciênc Saúde Coletiva. 2010 JanMar;15(2):321-7.

17. Brasil. Decreto n. 5.296 de 2 de dezembro de 2004. Regulamenta as Leis de n. 10.048, de 8 de novembro de 2000, que dá prioridade de atendimento às pessoas que especifica; e n.10.098, de 19 de dezembro de 2000, que estabelece normas gerais e critérios básicos para a promoção da acessibilidade das pessoas portadoras de deficiência ou com mobilidade reduzida. [internet]. Diário Oficial da República Federativa do Brasil. [acesso 2011 Jul
12]. Disponível em: http://www.planalto.gov.br/ ccivil_03/_ato2004-2006/2004/decreto/d5296.htm

18. França ISX, Pagliuca LMF. Inclusão social da pessoa com deficiência: conquistas, desafios e implicações para a enfermagem. Rev Esc Enferm USP. 2009 Mar; 43(1):170-7.

19. Barbosa MAM, Balieiro MMFG, Pettengill, MAM. Cuidado centrado na família no contexto da criança com deficiência e sua família: uma análise reflexiva. Texto Contexto Enferm. 2012 Jan-Mar; 21(1):194-9.

20. Araujo GB, Sperb TM. Crianças e a construção de limites: narrativas de mães e professoras. Psicol Estud. 2009 Jan-Mar;14(1):185-94. 